\title{
The study of risk factor for congenital dacryocystitis
}

\author{
Singh P. ${ }^{1}$, Raghuwanshi S. ${ }^{2}$, Satiza M. ${ }^{3}$ \\ ${ }^{1}$ Dr. Priti Singh, Assistant Professor, Gandhi Medical College, Bhopal M.P., ${ }^{2}$ Dr. Sapna Raghuwanshi, Assistant \\ Professor, Atal Bihari Vajpayee Government Medical College, Vidisha M.P., ${ }^{3}$ Dr. Manali Satiza, Third Year Junior \\ Resident, Department of Ophthalmology, PGI Rohtak, Haryana, India.
}

Corresponding Author: Dr. Sapna Raghuwanshi, M.S. Ophthalmology, Assistant Professor, Atal Bihari Vajpayee Medical College Vidisha M.P., India. E-mail- drsapnaraghuwanshi@gmail.com

\begin{abstract}
Background: Congenital nasolacrimal duct obstruction is inflammation of lacrimal sac due to nasolacrimal duct obstruction in children. Congenital nasolacrimal duct obstruction is a common disorder in infants, with up to $20 \%$ of all newborns suffering from epiphora during the first year of life. The purpose of this study is examining the various risk factors in patients of congenital nasolacrimal duct obstruction. Method: In this study, 121 patients were examined in L.N. Medical College and J.K Hospital, Kolar Road, Bhopal between June to July to August 2015.A clinical examination was being conducted in the children below age of 3 years after the history taking started by torch light examination, slit lamp examination, and the regurgitation test was being done. All the other conditions which presented like complaints of congenital Dacryocystitis like-Opthalmia Neonatorum, Congenital Glaucoma, allergic conjunctivitis, trauma to eye were being ruled out. Mothers of the children were asked to fill the Questionnaire about risk factor of Congenital nasolacrimal duct obstruction. The awareness about the disease in the mothers via the above questionnaire whether the mothers were familiar with the disease or not was asked. Results: 121 patients were seen over the period under review out of which $60 \%$ were males. Most common age at the presentation was between 0 to 2 months. 2 significant risk factors were observed, Prematurity and Poor hygienic status in this study. Conclusion: Current study done to find association of various risk factors. A further study is needed in this field to find any other risk factors responsible for the high incidence of congenital Dacryocystitis and all the mothers need to be educated regarding these risk factors, and awareness should be created in the mothers.
\end{abstract}

Keywords: Congenital, Nasolacrimal, Dacryocystitis, Prematurity, Hygiene.

\section{Introduction}

Congenital Dacryocystitis is inflammation of lacrimal sac due to nasolacrimal duct obstruction in children. Congenital nasolacrimal duct obstruction is a common disorder in infants, with up to $20 \%$ of all newborns suffering from epiphora during the first year of life [1]. Symptomatic Congenital nasolacrimal duct obstruction (CNLDO) probably occurs in 5 to $6 \%$ of infants [2]. However, during their first year of life, most CNLDO patients resolve spontaneously or with just conservative management such as lacrimal massage or antibiotic eye drops [3, 4]. Eighty-nine percent of the nasolacrimal ducts were opened with medical management only in the first sixteen months of life [5]. A comparatively high percentage of resolution for CNLDO (82.9\%) following conservative management was shown before the 1 st year of age in Japanese infants.

Manuscript received: $4^{\text {th }}$ July 2019

Reviewed: $14^{\text {th }}$ July 2019

Author Corrected: $20^{\text {th }}$ July 2019

Accepted for Publication: $27^{\text {th }}$ July 2019
Etiology of CNLDO is most commonly a membranous obstruction at level of valve of Hasner or stenosis of the duct or non-canalization. Incomplete canalization is the most common cause of CNLDO and occurs at the distal end resulting in an imperforate membrane at the valve of Hasner [6]. Other cause is proximal lacrimal outflow dysgenesis which occurs due to maldevelopment of punctum and canaliculus. There is no sex predilection or genetic predisposition, but congenital inflammation of lacrimal sac mostly occurs in poor socioeconomic conditions with poor hygiene status.

The child presents with the history of mucous discharge and epiphora of one or both the eyes, and regurgitation of purulent material into the eye can lead to conjunctivitis. Sometimes the periocular skin is chapped and on examination the regurgitation test is positive. A congenital lacrimal sac mucocele presents as a swelling over the sac area and when infected Dacryocystitis 
occurs, there is a swelling and erythema over the sac with palpable mass .The mass can be decompressed with digital pressure resulting in an regurgitation of purulent material through the puncta. Congenital nasolacrimal duct obstruction is associated with anisometropic amblyopia. Children with congenital nasolacrimal duct obstruction need to be followed to make certain they do not develop anisometropic amblyopia.

\section{Material and Method}

The study was carried out at J.K hospital, Kolar Road, Bhopal between July to August 2015.

Type of study- This is a cross sectional observational study

Ethical consideration \& permission- Informed consent was being taken from the mothers along with the proper approval from the ethical committee.

Inclusion criteria- All the children below the age of 3 years who presented with the complaints of watering and discharge attending ophthalmology and pediatric OPD were included in the study. All enrolled subjects were received complete ophthalmological examination including, slit lamp biomicroscopy, the regurgitation test.

\section{Result}

121 cases were included in the study who presented with complaints of watering and discharge. Out of the total 121 cases 55 had congenital Dacryocystitis. In present study Unilateral eye involvement was more common (76.36\%), and from that left eye involvement was more common (61.9\%) (Table 1). Overall maximum children presented to us with in the first year of life $(76.36 \%)$, only $18.18 \%$ children in $2^{\text {nd }}$ year of life and only $0.054 \%$ children were seen between the $2^{\text {nd }}$ and $3^{\text {rd }}$ year of life (Table 2). Further analysis was being done at the age at presentation within the $1^{\text {st }}$ year of life and it was seen that maximum cases were seen between 0 to 2 months of age (33.33\%) followed by 2 to 4 months $(23.80 \%)$ and very few of the cases were seen after the 6 months of age (Table 3). In present study discharge (67.27\%) were the main complaint followed by epiphora (32.72\%) (Table 4).

Table-1: Table showing distribution of cases of congenital nasolacrimal duct obstruction as per involvement of eye

\begin{tabular}{|c|c|c|}
\hline Eye involved & No of cases & Percentage \\
\hline Unilateral & 42 & 76.36 \\
\hline Right eye & 16 & 38.09 \\
\hline Left eye & 26 & 61.9 \\
\hline Bilateral & 13 & 23.63 \\
\hline
\end{tabular}

Table-2: Table showing age distribution of cases of congenital nasolacrimal duct obstruction.

\begin{tabular}{|c|c|c|}
\hline Age group in years & No. of cases & Percentage \\
\hline $0-1$ & 42 & 76.36 \\
\hline $1-2$ & 13 & 18.18 \\
\hline $2-3$ & 3 & 0.054 \\
\hline
\end{tabular}

Tropical Journal of Ophthalmology and Otolaryngology 
Table-3: Table showing age distribution within the $1^{\text {st }}$ year of life of cases of congenital nasolacrimal duct obstruction

\begin{tabular}{|c|c|c|}
\hline Age group in month & No. of cases & Percentage \\
\hline $0-2$ months & 14 & 33.33 \\
\hline $2-4$ months & 10 & 23.80 \\
\hline $4-6$ months & 7 & 16.66 \\
\hline 6-8 months & 5 & 11.19 \\
\hline 8-10 months & 3 & 7.14 \\
\hline $10-12$ months & 3 & 7.14 \\
\hline
\end{tabular}

Table-4: Table showing various symptoms at the time of presentation in cases of congenital nasolacrimal duct obstruction

\begin{tabular}{|l|c|}
\hline Symptoms & Percentage \\
\hline Discharge & 67.27 \\
\hline Epiphora & 32.72 \\
\hline
\end{tabular}

Table-5: Table showing different risk factor in cases of congenital nasolacrimal duct obstruction

\begin{tabular}{|c|c|c|c|c|}
\hline Parameters & Subgroups & *CNLDO + & *CNLDO- & $\mathrm{P}$ value** \\
\hline \multirow[t]{2}{*}{ Gender } & Male & 33 & 35 & 0.441 \\
\hline & Female & 22 & 31 & \\
\hline \multirow[t]{2}{*}{ Place of living } & Urban & 23 & 30 & 0.688 \\
\hline & Rural & 32 & 36 & \\
\hline \multirow[t]{2}{*}{ Hygienic status } & Good & 16 & 46 & 9E-06 \\
\hline & Poor & 39 & 20 & \\
\hline \multirow[t]{2}{*}{ Maternal nutrition in pregnancy } & Good & 29 & 36 & 0.841 \\
\hline & Poor & 26 & 30 & \\
\hline \multirow[t]{2}{*}{ Vaginal infection during pregnancy } & Present & 7 & 5 & 0.345 \\
\hline & Absent & 48 & 61 & \\
\hline \multirow[t]{2}{*}{ Birth weight } & $<2.5 \mathrm{~kg}$ & 20 & 16 & 0.146 \\
\hline & $>2.5 \mathrm{~kg}$ & 35 & 50 & \\
\hline \multirow[t]{2}{*}{ Smoking status of mother } & Smoker & 3 & 4 & 0.886 \\
\hline & Non-Smoker & 52 & 62 & \\
\hline \multirow[t]{2}{*}{ Radiation exposure during pregnancy } & Yes & 2 & 5 & 0.355 \\
\hline & No & 53 & 61 & \\
\hline \multirow[t]{2}{*}{ H/o any addiction } & Present & 0 & 2 & 0.192 \\
\hline & Absent & 55 & 64 & \\
\hline \multirow[t]{2}{*}{ Drug intake in Pregnancy } & Present & 4 & 6 & 0.717 \\
\hline & Absent & 51 & 60 & \\
\hline \multirow[t]{2}{*}{ Presentation of baby } & Cephalic & 48 & 54 & 0.411 \\
\hline & Breech & 7 & 12 & \\
\hline \multirow[t]{2}{*}{ Age at birth } & Full term $(>37$ weeks $)$ & 21 & 50 & $2.9 \mathrm{E}-05$ \\
\hline & Preterm $(<37$ weeks $)$ & 34 & 16 & \\
\hline \multirow[t]{2}{*}{ Site of delivery } & Hospital & 50 & 55 & 0.220 \\
\hline & Home & 5 & 11 & \\
\hline \multirow[t]{2}{*}{ Mode of Delivery } & Cesarean & 38 & 36 & 0.102 \\
\hline & Normal & 17 & 30 & \\
\hline \multirow[t]{2}{*}{ Any infection at Birth } & Present & 10 & 12 & 1.00 \\
\hline & Absent & 45 & 54 & \\
\hline \multirow[t]{2}{*}{ Congenital Dc in Sibling } & Present & 6 & - & \\
\hline & Absent & 49 & - & \\
\hline
\end{tabular}


$*(\mathrm{CNLDO}=$ congenital nasolacrimal duct obstruction. $)$

$* *$ Chi square value, significant if $\mathrm{p}<0.05$

We found 2 significant risk factors in this study. other risk factor were not significant (Table 5).

Prematurity- 21 of the 55 cases was born full term while 34 were premature and from the above data prematurity was found to be a significant risk factor that may be associated with the congenital Dacryocystitis $(\mathrm{P}=2.9 \mathrm{E}-05)$.

Poor hygienic status- Table showed that 16 of them had good hygienic status while 39 had a poor hygienic status, and from above calculation this factor is found to be a significant risk factor $(\mathrm{P}=9 \mathrm{E}-06)$.

Awareness status among the mothers was being checked and it was found that out of mothers of total 55 confirmed cases of congenital Dacryocystitis only 10 were concerned and aware about the congenital Dacryocystitis in infancy.

\section{Discussion}

Congenital NLD obstruction is found relatively frequently. In the current study out of total 50 premature children $34(68 \%)$ had an evidence of CNLDO while only $21(42 \%)$ of the full term born children $(\mathrm{P}=2.9 \mathrm{E}$ 05) had congenital Dacryocystitis and these observations were similar to those made Lorena $\mathrm{S}$ et al which were compared to the CNLDO in the premature and full term children showed that of the 200 premature children, $32(16 \%)$ had CNLDO compared with 7 (3.5\%) of the 200 full-term infants $(\mathrm{P}<0.0001)$ [7]. Male preponderance was observed in the present study, $60 \%$ patients were male. These observations are similar to those made Nordlow and Yennerholm [8].

In the present study it was observed that the age at presentation and the maximum children (76.36\%) presented within the first year of life and from these 42 cases in 1st year of life it was seen that maximum cases $(33.33 \%)$ were seen between 0 to 2 months of age. These observations were similar to those made Macewen $\mathrm{C} J$ et al they showed that in $95 \%$ of cases the onset of epiphora or discharge occurred during the first month of life. In all of the above studies maximum children presented with in $1^{\text {st }}$ year of life and the further difference seen may be due to different geographical areas [9].

In the present study, it was found the main symptom at the presentation was Discharge in the 37 cases $(67.2 \%)$ while epiphora in the 18 cases $(32.7 \%)$ the results were similar to study done at Sheffield children hospital [10]. They also explained that discharge was said to be the main symptom in 217 cases $(63.2 \%)$ and epiphora in 126 cases $(36.73 \%)$. and from the above data it can be concluded that discharge is more commonly seen than epiphora and this may be due to parents are more concerned about when child is having discharge rather than the child having watering this is why they are brought to the hospital.
The current study also showed the association of living status of the children and their family and it was found that out of maximum children $(58.1 \%)$ presented to us resided in rural area while $23(41.8 \%)$ belonged to urban residency. And the result to be similar to study done by Aldahash F et al [11].

\section{Conclusion}

In current study done to find association of various risk factors, 2 significant risk factors were observed:

\section{Prematurity \\ 2. Poor hygienic status}

And rest factors were not significantly associated with the disease.

There is a wealth of data showing that CNLDO is a disease where early and effective treatment has been shown to reduce significantly the incidence of surgical intervention. However, in the present study sample size was insufficient to subgroup patients and compares the. Thus, a further study with larger sample size is recommended.

A further study is needed in this field to find any other risk factors responsible for the high incidence of congenital Dacryocystitis

\section{What the study adds to the existing study?}

In this study it was found that prematurity and poor hygienic status were the two significant factor so early referral of child for treatment is very important.

All the mothers need to be educated regarding these risk factors, and awareness should be created in the mothers by educating them about the disease and maintaining hygienic status at home. 


\section{Author's contribution}

Dr. Sapna and Dr. Priti have prepared the manuscript after doing various test of CNLDO as well as in normal subjects. Dr. Sapna has been assisted by Dr. Manali during preparation of manuscript.

Funding: Nil, Conflict of interest: Nil Permission from IRB: Yes

\section{References}

1. Macewen CJ. Congenital nasolacrimal duct obstruction. Compr Ophthalmol Update. 2006; 7 (2): 79-87

2. Paul TO, Shepherd R. Congenital nasolacrimal duct obstruction: natural history and the timing of optimal intervention. J Pediatr Ophthalmol Strabismus. 1994;31 (6): $362-367$.

3. Young JD, Mac Ewen CJ. Managing congenital lacrimal obstruction in general practice. BMJ. 1997; 315 (7103):293-296. doi:10.1136/bmj.315.7103.293

4. Kapadia MK, Freitag SK, Woog JJ. Evaluation and management of congenital nasolacrimal duct obstruction. Otolaryngol Clin North Am. 2006;39(5): 959-977, vii. doi:10.1016/j.otc.2006.08.004

5. Paul TO. Medical management of congenital nasolacrimal duct obstruction. Pediatr Ophthalmol Strabismus. 1985;22(2):68-70.
6. Repka MX, Melia BM, Beck RW, Chandler DL, Fishman DR, Goldblum TA et al Primary treatment of nasolacrimal duct obstruction with balloon catheter dilation in children younger than 4 years of age. $J$ AAPOS. 2008; 12(5): 451-455.doi: 10.1016/j.jaapos. 2008. 07.001

7. Lorena SH, Silva JA, Scarpi MJ. Congenital nasolacrimal duct obstruction in premature children. $\mathrm{J}$ Pediat Ophthalmol Strabis. 2013;50(4):239-244.doi: 10.3390/diseases6040096.

8. Nordlow W, Vennerholm I. Congenital atresiae of the lacrimal passages: their occurrence and treatment. Acta Ophthalmol. 1953;31(4):367-371.

9. MacEwen CJ, Young JD. Epiphora during the first year of life. Eye (Lond). 1991;5(Pt 5):596-600. doi:10. 1038/eye.1991.103

10. Ffooks OO. Dacryocystitis in infancy. $\mathrm{Br} \mathrm{J}$ Ophthalmol. 1962;46(7):422-434.doi:10.1136/bjo. 46.7. 422

11. Aldahash FD, Al-Mubarak MF, Alenezi SH, AlFaky YH. Risk factors for developing congenital nasolacrimal duct obstruction. Saudi journal of ophthalmology. 2014; 28(1):58-60. doi: 10.1016/j.sjopt. 2013. 09.007

\section{How to cite this article?}

Singh P, Raghuwanshi S, Satiza M. The study of risk factor for congenital dacryocystitis. Trop J Ophthalmol Otolaryngol.2019;4(4):291-295 doi:10.17511/jooo.2019.104.06 